\title{
NMR SPECTROSCOPIC AND X-RAY STRUCTURAL CHARACTERIZATION OF TWO DIARYL DERIVATIVES OF (4-CYANO-6-METHYL-3,8-DIOXO-2,3,5,6,7,8-HEXAHYDROPYRIDO|3,4- c]PYRIDAZIN-6-YL)HYDRAZONO-ACETIC ACID ETHYL ESTER
}

\author{
Katri Laihia, ${ }^{\text {* }}$ Erkki Kolehmainen, ${ }^{\prime}$ Elina Wegelius, ${ }^{\prime}$ Sergei Miltsov, ${ }^{2}$ Vladimir Nikiforov ${ }^{2}$ and Vladimir Karavan ${ }^{2}$
}

\author{
'Department of Chemistry, University of Jyväskylä, P.O.Box 35, FIN-40014, Jyväskylä, Finland \\ -St.Petersburg University, Institute of Chemistry, Universitetskii pr. 2, 198904 St.Petersburg, Russia
}

\begin{abstract}
H},{ }^{13} \mathrm{C}$ and ${ }^{15} \mathrm{~N}$ NMR chemical shifts have been measured and assigned for [4-cyano-2-(3,4dimethylphenyl)-6-methyl-3,8-dioxo-2,3,5,6,7,8-hexahydropyrido[3,4-c]pyridazin-6-yl-(3,4-dimethylphenyl)hydrazono]- and [4-cyano-2-(3-chloro,4-methylphenyl)-6-methyl-3,8-dioxo-2,3,5,6,7,8-hexahydropyrido[3,4-c]pyridazin-6-yl-(3-chloro,4-methylphenyl)hydrazono]-acetic acid ethyl esters. The structure of the first compound was also verified by a single crystal $\mathrm{X}$-ray analysis.
\end{abstract}

\section{Introduction}

Substituted heterocycles such as pyrimidines and piperazines have been largely synthesized using various nitriles as starting compounds (1-4). Ibrahim et al (1) used crotononitriles and arene diazonium salts to prepare pyridazine derivatives. Depending on the structure of the starting nitrile, the reaction products were either acyclic mono- or dihydrazones, which were cyclized to the corresponding pyridazine derivatives. In the present work the starting compound was ethylcyanoacetate, which in a reaction with a phenylhydrazono derivative gave in addition to the expected pyridazine derivative also an other reaction product, which proved to be a substituted pyrido[3,4-c]pyridazine. The pyrido[3,4-c]pyridazine was born, when the main reaction product reacted with a second phenylhydrazono molecule. In this paper we report the ${ }^{1} \mathrm{H},{ }^{13} \mathrm{C}$ and ${ }^{15} \mathrm{~N}$ NMR spectral data for two pyrido[3,4-c]pyridazine derivatives. The single crystal X-ray structure for one compound is also presented.

\section{Experimental}

[4-cyano-2-(3,4-dimethylphenyl)-6-methyl-3,8.dioxo-2,3,5,6,7,8-hexahydropyrido[3,4-c]pyridazin-6-yl-(3,4dimethylphenyl)-hydrazono]-acetic acid ethyl ester 1 and [4-cyano-2-(3-chloro,4-methylphenyl)-6-methyl-3,8.dioxo2,3,5,6,7,8-hexahydropyrido[3,4-c]pyridazin-6-yl-(3-chloro,4-methylphenyl)-hydrazono]-acetic acid ethyl ester 2 were prepared as an ca. $10 \%$ yield in an equimolar reaction both ethylcyanoacetate and 2-(3,4-dimethylphenylhydrazono)-3oxobutyrate (A) and 2-(3-chloro,4-methyl-phenylhydrazono)-3-oxobutyrate (B) with ethylcyanoacetate (C) in the presence of ammonium acetate $160^{\circ} \mathrm{C}$ for 1 hour. The main product were the expected 1-(3,4-substituted)-3-carbethoxy-4methyl-5-cyano-6-oxo-1,6-dihydropyridazines in ca. $70 \%$ yield (D/E). The synthesis reaction and the structures of starting compounds are presented in Figure 1. The numbering and the structures of the derivatives 1 and 2 are presented in Figure 2.

The ${ }^{1} \mathrm{H},{ }^{13} \mathrm{C}$ and ${ }^{15} \mathrm{~N}$ NMR spectra were recorded for about $0.5 \mathrm{M}$ DMSO- $\mathrm{d}_{6}$ solution in a 5 -mm sample tube at $30^{\circ} \mathrm{C}$ on a Bruker Avance $500 \mathrm{MHz}$ spectrometer equipped with an invelse detection probehead and 7.gradient accessory and working at $500.13,125.77$ and $50.69 \mathrm{MHz}$ respectively. The ${ }^{1} \mathrm{H},{ }^{13} \mathrm{C}$ and ${ }^{15} \mathrm{~N}$ NMR chemical shifts of com- 
<smiles>[X]c1cc(NN(N=C(C(C)=O)C(=O)OCC)c2ccc(N3N=C(C(=O)OCC)C(C)C(C#N)C3=O)c([X])c2)ccc1C</smiles><smiles>[X]c1cc(N2N=C(C(=O)OCC)C(C)C(C#N)C2=O)ccc1C</smiles><smiles>[X]c1cc(NN=C(C(C)=O)C(=O)OCC)ccc1C</smiles><smiles>CCOC(=O)CN</smiles>

Figure 1 . Synthesis reaction of compounds 1 and 2 .

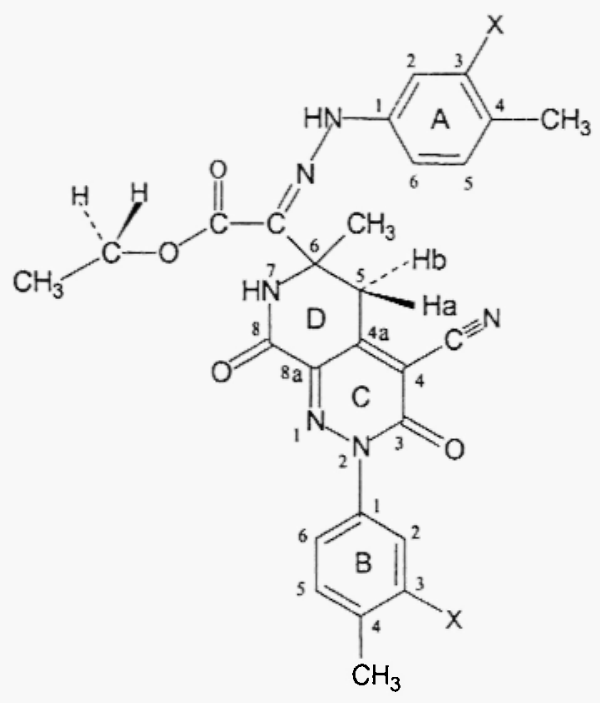

Figure 2. Compound 1, $\mathrm{X}=\mathrm{CH}_{3}$, compound 2. $\mathrm{X}=\mathrm{Cl}$. 
pounds 1 and 2 have been solved based on PFG (5) ${ }^{1} \mathrm{H},{ }^{13} \mathrm{C}$ HMQC $(6,7)$ and $\operatorname{HMBC}(8)$ as well as PEG ${ }^{1} \mathrm{H},{ }^{15} \mathrm{~N}$ $\mathrm{HMBC}$ experiments. DQF ${ }^{1} \mathrm{H},{ }^{1} \mathrm{H} \operatorname{COSY}(9,10)$ was measured for compound 2 . The ${ }^{1} \mathrm{H},{ }^{13} \mathrm{C}$ and ${ }^{15} \mathrm{~N}$ NMR chemical shifts are presented in Tables $1-3$.

In 'H NMR experiments the spectral width was $7000 \mathrm{~Hz}$, the number of data points $64 \mathrm{~K}$, which was zero filled to $128 \mathrm{~K}$ giving sa spectral resolution of $0.05 \mathrm{~Hz}$, the number of scans was $8-32$ and the flip angle $30^{\circ}$. An exponential window function of the spectral resolution was used prior to FT. The 'H NMR chemical shifts are referenced to the residual signal of DMSO- $\mathrm{d}_{6}, \mathrm{~d}=2.50 \mathrm{ppm}$ from TMS $(\delta=0.00 \mathrm{ppm})$.

Table 1. $\delta\left({ }^{1} \mathrm{H}\right)$ (ppm from TMS) of 1 and 2 in $0.5 \mathrm{M} \mathrm{DMSO}-\mathrm{d}_{6}$ at $30^{\circ} \mathrm{C}$.

\begin{tabular}{|c|c|c|}
\hline \multicolumn{3}{|c|}{$\delta\left({ }^{\prime} \mathrm{H}\right) / \mathrm{ppm}$} \\
\hline Proton & 1 & 2 \\
\hline $\mathrm{H}-2$ (ring $\mathrm{A}$ ) & 7.01 & 7.29 \\
\hline H-5 & 7.00 & 7.19 \\
\hline H-6 & 6.88 & 7.06 \\
\hline $3-\mathrm{CH}_{3}$ & 2.16 & - \\
\hline $4-\mathrm{CH}_{3}$ & 2.13 & 2.23 \\
\hline $\mathrm{NH}$ & 11.46 & 11.32 \\
\hline $\mathrm{H}-2$ (ring $\mathrm{B}$ ) & 7.13 & 7.49 \\
\hline H-5 & 7.22 & 7.47 \\
\hline $\mathrm{H}-6$ & 7.15 & 7.37 \\
\hline $3-\mathrm{CH}_{3}$ & 2.19 & - \\
\hline $4-\mathrm{CH}_{3}$ & 2.24 & 2.37 \\
\hline $\mathrm{Ha}\left(\mathrm{CH}_{2}\right.$, ring $\left.\mathrm{D}\right)$ & 3.38 & 3.42 \\
\hline $\mathrm{Hb}\left(\mathrm{CH}_{2}\right.$, ring D $)$ & 3.86 & 3.87 \\
\hline $\mathrm{CH}_{3}$ (ring D) & 1.71 & 1.69 \\
\hline $\mathrm{NH}$ (ring D) & 8.82 & 8.88 \\
\hline $\mathrm{H}\left(\mathrm{CH}_{2}\right.$, ethoxy $)$ & 4.30 & 4.31 \\
\hline $\mathrm{H}\left(\mathrm{CH}_{2}\right.$, ethoxy) & 4.37 & 4.36 \\
\hline $\mathrm{CH}_{3}$ (ethoxy) & 1.36 & 1.35 \\
\hline
\end{tabular}

In ${ }^{13} \mathrm{C}$ NMR experiments the spectral width was $31400 \mathrm{~Hz}(250 \mathrm{ppm})$, the number of data points $64 \mathrm{~K}$ giving a spectral resolution of $0.5 \mathrm{~Hz}$, the number of scans was $624-2700$ and the flip angle $30^{\circ}$. An exponential window function of the spectral resolution was used prior to FT. The ${ }^{13} \mathrm{C}$ NMR chemical shifts are referenced to the centre peak of the solvent DMSO- $\mathrm{d}_{6}, \delta=39.50 \mathrm{ppm}$ from TMS $(\delta=0.00 \mathrm{ppm})$.

In two dimensional PFG ${ }^{1} \mathrm{H},{ }^{13} \mathrm{C}$ HMQC and $\mathrm{HMBC}$ measurements the matrix sizes were $1024\left(\mathrm{f}_{2}\right) \times 256\left(\mathrm{f}_{1}\right)$, which were zero filled to $2048 \times 512$ and apodized by a shifted sine bell window function along both axes prior to FT. In PFG ${ }^{1} \mathrm{H},{ }^{13} \mathrm{C} \mathrm{HMBC}$ a $50 \mathrm{~ms}$ delay was inserted in the pulse program for evolution of long range couplings (optimum at 10 $\mathrm{Hz}$ ). In addition, a low pass filter was used in the beginning of the $\mathrm{HMBC}$ pulse program to remove the correlations due to direct couplings. Similarly, in PFG ${ }^{1} \mathrm{H},{ }^{15} \mathrm{~N}$ HMBC experiments a $50 \mathrm{~ms}$ delay was used for evolution of long range couplings. The number of data points was $1024\left(f_{2}\right) \times 512\left(f_{1}={ }^{15} \mathrm{~N}\right)$. This matrix was zero filled to $1024 \times 1024$ and apodized by a shifted sine bell window function along both axes prior to FT. In ${ }^{15} \mathrm{~N}$ NMR experiments the chemical shifts are referenced to the signal of external $\mathrm{CH}_{3} \mathrm{NO}_{2}$ in a $1 \mathrm{~mm}$ diameter capillary tube inserted coaxially in the 5 mun NMR tube, $\delta\left(\mathrm{CH}_{3}{ }^{15} \mathrm{NO}_{2}\right)=0.0 \mathrm{ppm}$. 
In DQF ${ }^{1} \mathrm{H},{ }^{1} \mathrm{H}$ COSY measurements the matrix size was $512\left(f_{1}\right) \times 2048\left(f_{2}\right)$, which was zero filled to $1024 \times$ 2048 and multiplied by sinebell window function prior to FT.

Table 2. $\delta\left({ }^{13} \mathrm{C}\right.$ ) (ppm from TMS) of 1 and 2 in $0.5 \mathrm{M} \mathrm{DMSO}-\mathrm{d}_{6}$ at $30^{\circ} \mathrm{C}$

\begin{tabular}{|c|c|c|}
\hline \multirow[b]{2}{*}{ Carbon } & \multicolumn{2}{|c|}{$\delta\left({ }^{13} \mathrm{C}\right) / \mathrm{ppm}$} \\
\hline & 1 & 2 \\
\hline $\mathrm{C}-1$ (ring $\mathrm{A})$ & 140.86 & 142.55 \\
\hline $\mathrm{C}-2$ & 115.03 & 114.12 \\
\hline C-3 & 137.20 & 133.93 \\
\hline $\mathrm{C}-4$ & 129.99 & 128.34 \\
\hline C-5 & 130.03 & 131.44 \\
\hline$C-6$ & 111.52 & 112.73 \\
\hline $3-\mathrm{CH}_{3}$ & 19.43 & - \\
\hline $4-\mathrm{CH}_{3}$ & 18.59 & 18.76 \\
\hline C-1 (ring B) & 138.09 & 139.04 \\
\hline $\mathrm{C}-2$ & 126.10 & 125.72 \\
\hline C-3 & 136.97 & 132.94 \\
\hline C-4 & 137.61 & 136.76 \\
\hline C-5 & 129.52 & 131.13 \\
\hline C-6 & 122.74 & 124.17 \\
\hline $3-\mathrm{CH}_{3}$ & 19.15 & - \\
\hline $4-\mathrm{CH}_{3}$ & 19.01 & 19.28 \\
\hline $\mathrm{C}-3$ (ring $\mathrm{C} / \mathrm{D}$ ) & 156.17 & 156.09 \\
\hline$C-4$ & 110.77 & 111.26 \\
\hline$C-4 a$ & 150.13 & 149.82 \\
\hline$C-5$ & 38.26 & 38.08 \\
\hline C- 6 & 57.28 & 57.34 \\
\hline C-8 & 159.40 & 159.55 \\
\hline$C-8 a$ & 135.39 & 135.64 \\
\hline $\mathrm{CN}$ & 112.97 & 112.77 \\
\hline $6-\mathrm{CH}_{3}$ & 25.94 & 25.73 \\
\hline $\mathrm{C}=\mathrm{N}$ & 128.30 & 130.22 \\
\hline $\mathrm{CO}$ (ester) & 161.90 & 161.63 \\
\hline $\mathrm{CH}_{2}$ & 61.16 & 61.40 \\
\hline $\mathrm{CH}_{3}$ & 13.89 & 13.83 \\
\hline
\end{tabular}

Table 3. $\delta\left({ }^{15} \mathrm{~N}\right)$ (ppm from ext. $\mathrm{CH}_{2} \mathrm{NO}_{2}$ ) of 1 and 2 in $0.5 \mathrm{M} \mathrm{DMSO}-\mathrm{d}_{6}$ at $30^{\circ} \mathrm{C}$

\begin{tabular}{lcc}
\hline Nitrogen & 1 & $-\delta\left({ }^{15} \mathrm{~N}\right) / \mathrm{ppm}$ \\
& & 2 \\
\hline NH (ring A) & 227.7 & 230.8 \\
$\mathrm{~N}-1$ (ring C) & 25.3 & 27.4 \\
$\mathrm{~N}-2$ (ring C) & 160.0 & 162.8 \\
$\mathrm{NH}$ (ring D) & 248.2 & 248.3 \\
$\mathrm{~N}=\mathrm{C}$ & 34.6 & 37.8 \\
$\mathrm{NC}$ & not obs. & not obs.
\end{tabular}


Crystals for single crystal X-ray analysis of compound 1 were obtained by slow evaporation from DMSO-d $\mathrm{d}_{6}$ solution in sealed NMR tube. The X-ray structural data were collected with a Nonius Kappa CCD diffractometer at $173.0+0.1 \mathrm{~K}$ using graphite monochromatised $\mathrm{MoK}_{\alpha}$ radiation $(\lambda=0.71073 \AA)$. Data were processed with DENZOSMN (11), the structure was solved by direct methods (SHELXS-97) (12) and refined on $F^{2}$ (SHELXL-97) (13).The reflections were corrected for Lorenz polarisation effects, absorption correction was not used. The hydrogen atoms were calculated to their idealised positions and refined with isotropic temperature factors (1.2 or 1.5 times the $C$ temperature factor). No hydrogens were determined to a water molecule. Three of the sulphurs of the DMSO molecules are disordered over two positions. In addition one oxygen of a DMSO molecule is disordered over two positions. Other experimental X-ray data are shown in Table 4 and the ORTEP of 1 is illustrated in Figure 3.

Crystallographic data (excluding structure factors) for the structure has been deposited with the Cambridge Crystallographic Data Centre as supplementary publication no. CCDC-201440. Copies of the data can be obtained free of charge on application to CCDC, 12 Union Road, Cambridge CB2 1 EZ UK.

Table 4. Experimental data for single crystal X-ray diffraction studies

\begin{tabular}{cc}
\hline Formula & $2 \mathrm{C}_{29} \mathrm{H}_{30} \mathrm{~N}_{6} \mathrm{O}_{4} \cdot 8\left(\mathrm{CH}_{3}\right)_{2} \mathrm{SO} \cdot \mathrm{H}_{2} \mathrm{O}$ \\
\hline Formula weight $\left(\mathrm{g} \cdot \mathrm{mol}^{1}\right)$ & 1694.3 \\
Crystal system & Monoclinic \\
Space group & $\mathrm{P} 2$ ( No. 4) \\
Crystal size $(\mathrm{mm})$ & $0.15 \times 0.20 \times 0.40$ \\
$a(\AA)$ & $11.5122(2)$ \\
$b(\AA)$ & $32.0092(7)$ \\
$c(\AA)$ & $11.9449(2)$ \\
$\beta\left({ }^{\circ}\right)$ & $95.101(2)$ \\
$\mathrm{V}\left(\AA^{3}\right)$ & $4384.2(1)$ \\
$Z$ & 2 \\
$\mathrm{D}(\mathrm{calc}).\left(\mathrm{g} \cdot \mathrm{cm}^{-1}\right)$ & 1.283 \\
$\mu\left(\mathrm{MoK}_{\mathrm{\alpha}}\right)\left(\mathrm{mm}^{-1}\right)$ & 0.272 \\
$\theta$ range for data collection $\left({ }^{\circ}\right)$ & $2.65-25.04$ \\
No. of reflections measured & 17677 \\
No. of reflections observed $(I>2 \sigma(I))$ & 9974 \\
No. of parameters & 1052 \\
$\mathrm{R} / \mathrm{R}_{w}$ for unique data with $I>2 \sigma(I)(\%)$ & $5.35 / 12.20$ \\
GoF & 1.091 \\
\hline
\end{tabular}

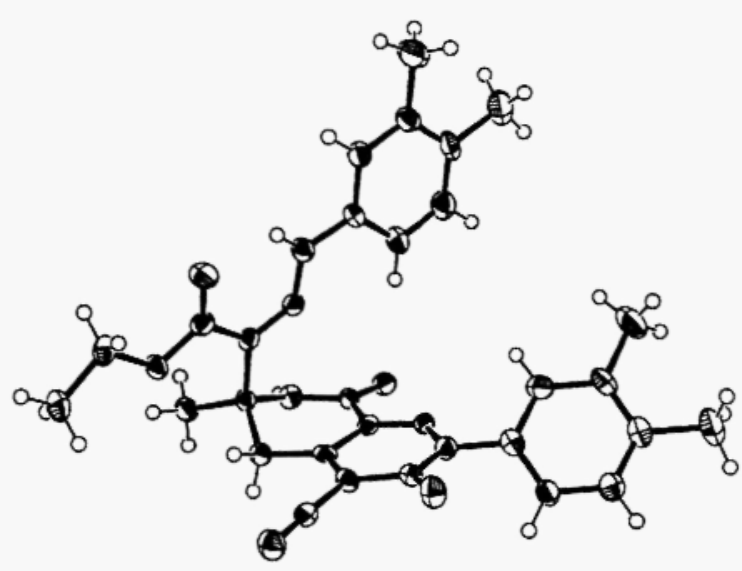

Figure 3. The ORTEP of compound 1. 
ESI-TOF mass spectral studies gave the molecular formula of $\mathrm{C}_{29} \mathrm{H}_{30} \mathrm{~N}_{6} \mathrm{O}_{4}$ for compound 1 and $\mathrm{C}_{27} \mathrm{H}_{24} \mathrm{~N}_{6} \mathrm{O}_{4} \mathrm{Cl}_{2}$ for compound 2 .

\section{Results and discussion}

The synthesis reaction and the structures of the starting compounds are presented in Figure 1. The numbering and the structures of the two derivatives 1 and 2 are presented in Figure 2.

NMR: The assignment of the NMR chemical shifts was started from the ${ }^{1} \mathrm{H}$ chemical shifts of 1 (Figure 2), because its single crystal $\mathrm{X}$-ray structure was available. The $\delta\left({ }^{1} \mathrm{H}\right)$ of the ethoxy-group are at $1.36 \mathrm{ppm}$ (triplet) and at 4.30 and $4.37 \mathrm{ppm}\left(\mathrm{AB}\right.$-quartet because these methylene protons are diastereotopic) showing ${ }^{3} J(\mathrm{H}, \mathrm{H})=7.1 \mathrm{~Hz}$ and ${ }^{2} J(\mathrm{H}, \mathrm{H})$ $=-10.7 \mathrm{~Hz}$. coupling constants.

The $\delta\left({ }^{\prime} \mathrm{H}\right)$ assignments of two $\mathrm{ABC}$-spin systems in the rings $\mathrm{A}$ and $\mathrm{B}$ are based on the characteristic ${ }^{3} J(\mathrm{H}, \mathrm{H})$ and ${ }^{4} \mathrm{~J}(\mathrm{H}, \mathrm{H})$ coupling constants as well as PFG DQF ${ }^{1} \mathrm{H},{ }^{1} \mathrm{H}$ COSY measurements. After that PFG ${ }^{1} \mathrm{H},{ }^{13} \mathrm{C}$ HMQC gave unambiguous ${ }^{13} \mathrm{C}$ assignments for the corresponding protonated carbons. The final step in the assignment of the ring $\mathrm{A}$ was PFG ${ }^{1} \mathrm{H},{ }^{13} \mathrm{C}$ HMBC cross peak (evolution delay $50 \mathrm{~ms}$ ) between $\mathrm{NH}$ proton at $11.46 \mathrm{ppm}$ and a carbon at 111.52 ppm, which is C-6 bound to H-6 at $6.88 \mathrm{ppm}$. This was they key observation, which helped to solve all the $\delta\left({ }^{i} \mathrm{H}\right)$ and $\delta\left({ }^{13} \mathrm{C}\right)$ shifts of rings $\mathrm{A}$ and $\mathrm{B}$.

There exist only two $\mathrm{NH}$-protons as revealed by PFG ${ }^{\mathrm{H}} \mathrm{H},{ }^{15} \mathrm{~N}$ HMBC, when the low-pass filter was miss-set to give these cross-peaks as doublets (in inv4gslplmd pulse program the proton decoupler is off during the acquisition). The other amino proton at $8.82 \mathrm{ppm}$, which can't show cross-peaks with aromatic carbons is N-7.

The $\delta\left({ }^{1} \mathrm{H}\right)$ of the methyls in the rings $\mathrm{A}$ and B resonating from 2.13 to $2.24 \mathrm{ppm}$ were assigned based on PFG ${ }^{1} \mathrm{H},{ }^{13} \mathrm{C}$ HMBC cross peaks. Their $\delta\left({ }^{13} \mathrm{C}\right)$ are correlated with the following protons in the ring A: $18.59 \mathrm{ppm}\left(4-\mathrm{CH}_{3}\right)$ with $7.00 \mathrm{ppm}(\mathrm{H}-5) ; 19.43 \mathrm{ppm}\left(3-\mathrm{CH}_{3}\right)$ with $7.01 \mathrm{ppm}(\mathrm{H}-2)$. Similarly in the ring B: $19.01 \mathrm{ppm}\left(4-\mathrm{CH}_{3}\right)$ with 7.22 ppm (H-5) and $19.15 \mathrm{ppm}\left(3-\mathrm{CH}_{3}\right)$ with $7.13 \mathrm{ppm}(\mathrm{H}-2)$. The singlet of three protons at $1.71 \mathrm{ppm}$, belongs to the methyl group on $\mathrm{sp}^{3}$-hybridized $\mathrm{C}-6$, in the ring $\mathrm{D}$.

An other $A B$-quartet at $\delta\left({ }^{1} \mathrm{H}\right)=3.38$ and $3.86 \mathrm{ppm}$ must belong to the geminal protons at $\mathrm{C}-5$ (ring D), which also is ascertained by a PFG ${ }^{1} \mathrm{H},{ }^{13} \mathrm{C}$ HMBC cross-peak between $7-\mathrm{NH}$ and $\mathrm{C}-5$ at $38.26 \mathrm{ppm}$.

As stated before the assignments of the $\delta\left({ }^{\prime} \mathrm{H}\right)$ of the amino protons at $8.82 \mathrm{ppm}$ and $11.46 \mathrm{ppm}$ are based on PFG ${ }^{1} \mathrm{H},{ }^{15} \mathrm{~N}$ HMBC. Among them $\delta\left({ }^{1} \mathrm{H}\right)$ at $8.82 \mathrm{ppm}$ shows $\mathrm{PFG}{ }^{1} \mathrm{H},{ }^{13} \mathrm{C}$ HMBC cross peak with $\mathrm{C}-5$ at 38.26 ppm and $\mathrm{C}-6$ (methyl) at $25.94 \mathrm{ppm}$ in the ring $\mathrm{D}$ whereas the amino proton resonating at $\delta\left({ }^{\mathrm{t}} \mathrm{H}\right)$ at $11.46 \mathrm{ppm}$ is too far from the $\mathrm{D}$ ring to show any cross-peaks transmitted by long-range couplings.

The assignments of the fifteen non-protonated $\delta\left({ }^{13} \mathrm{C}\right)$ as well as $\delta\left({ }^{15} \mathrm{~N}\right)$ are all based on the PFG ${ }^{1} \mathrm{H},{ }^{13} \mathrm{C}$ and ${ }^{1} \mathrm{H},{ }^{15} \mathrm{~N}$ HMBC experiments. The ipso-carbons of the aromatic rings were elucidated as follows: $\delta\left({ }^{13} \mathrm{C}\right) 129.99 \mathrm{ppm}$ is strongly correlated with the $2.16 \mathrm{ppm}\left(3-\mathrm{CH}_{3}\right), 2.13 \mathrm{ppm}\left(4-\mathrm{CH}_{3}\right), 7.01 \mathrm{ppm}(\mathrm{H}-2$, ring A) and $6.88 \mathrm{ppm}(\mathrm{H}-6$, ring A) and thus belongs to $\mathrm{C}-4$ of the ring $\mathrm{A} . \delta\left({ }^{13} \mathrm{C}\right)$ shift of $137.20 \mathrm{ppm}$, which is correlated with the protons $7.00 \mathrm{ppm}(\mathrm{H}-5$, ring $\mathrm{A}$ ) and $2.16 \mathrm{ppm}\left(4-\mathrm{CH}_{3}\right)$ belongs to $\mathrm{C}-3$ (ring A). $\delta\left({ }^{13} \mathrm{C}\right.$ ) shift of $\mathrm{C}-1$ (ring A) has shift value of $140.86 \mathrm{ppm}$, because that carbon shift is correlated with $11.46 \mathrm{ppm}(\mathrm{NH})$ and $7.00 \mathrm{ppm}(\mathrm{H}-5$, ring $\mathrm{A})$.

The assignment of ${ }^{1} \mathrm{H}$ and ${ }^{13} \mathrm{C}$ chemical shifts in ring $\mathrm{B}$ was similarly based on the $\mathrm{PFG}{ }^{1} \mathrm{H},{ }^{13} \mathrm{C}$ HMQC and HMBC experiments. The $\delta\left({ }^{13} \mathrm{C}\right)=57.28 \mathrm{ppm}$ belongs to the $\mathrm{sp}^{3}$-hybridized $\mathrm{C}-6$ (ring $\mathrm{D}$ ). This is proved by its correlation with $8.82 \mathrm{ppm}\left(\mathrm{N}^{1} \mathrm{H}\right), 3.86 \mathrm{ppm}, 3.38 \mathrm{ppm}\left(5-\mathrm{CH}_{2}\right)$ and $1.17 \mathrm{ppm}\left(6-\mathrm{CH}_{3}\right)$.

The ester carbonyl shift of $161.90 \mathrm{ppm}$, was assigned from its correlation with $\mathrm{CH}_{2}$ protons (4.30 and $4.37 \mathrm{ppm}$ ). The two other carbonyl shifts, C-3 (ring C/D) of $156.17 \mathrm{ppm}$ and C-8 (ring D) of $159.40 \mathrm{ppm}$ were elucidated as fol- 
lows. The $\delta\left({ }^{13} \mathrm{C}\right)=156.17$ is correlated with $\delta\left({ }^{1} \mathrm{H}\right)=3.38 \mathrm{ppm}$, with one of the $5-\mathrm{CH}_{2}$ protons (ring $\mathrm{D}$ ), while the $\delta\left({ }^{13} \mathrm{C}\right)=159.40 \mathrm{ppm}$ is correlated with $\delta\left({ }^{\prime} \mathrm{H}\right)=1.71 \mathrm{ppm}\left(6-\mathrm{CH}_{3}\right.$ of ring $\left.\mathrm{D}\right)$ and $\delta\left(\mathrm{N}^{\prime} \mathrm{H}\right)=8.82 \mathrm{ppm}$. Only $\mathrm{C}-8$ carbonyl can correlate with $\mathrm{NH}$ and $6-\mathrm{CH}_{3}$ protons of ring $\mathrm{D}$.

The rest of the non protonated carbons $\mathrm{C}-4$ (ring C), C-4a (ring C/D), C-8a (ring C/D), $\mathrm{CN}$ (ring C) and $\mathrm{C}=\mathrm{N}$ (hydrazono group) have following $\delta\left({ }^{13} \mathrm{C}\right): 110.77 \mathrm{ppm}, 150.13 \mathrm{ppm}, 135.39 \mathrm{ppm}, 112.97 \mathrm{ppm}$ and $128.30 \mathrm{ppm}$. From these only the $\delta\left({ }^{13} \mathrm{C}\right)=128.30 \mathrm{ppm}$ is strongly correlated with the $\delta\left(\mathrm{N}^{1} \mathrm{H}\right)=11.46 \mathrm{ppm}$ and thus belongs to the hydrazono group. The $\delta\left({ }^{13} \mathrm{C}\right)$ shifts of $110.77 \mathrm{ppm}$ and $135.59 \mathrm{ppm}$ are both strongly correlated with both methylene protons $3.38 \mathrm{ppm}$ and $3.86 \mathrm{ppm}$ in the ring $\mathrm{D}$. The latter is also strongly correlated with $\mathrm{NH}$ proton $(8.82 \mathrm{ppm})$ and thus belongs to $\mathrm{C}-8 \mathrm{a}$, while the $110.77 \mathrm{ppm}$ shift belongs to $\mathrm{C}-4$. The $\delta\left({ }^{13} \mathrm{C}\right)$ shift of $112.97 \mathrm{ppm}$ is correlated with $3.38 \mathrm{ppm}$ proton shift and very weakly with $3.86 \mathrm{ppm}$. These couplings are over four bonds, between the cyano carbon and the $5-\mathrm{CH}_{2}$ (ring D) protons. The typical shift area for cyano carbon is between 110.5 to $125.1 \mathrm{ppm}$ (14).The last non protonated $\delta\left({ }^{13} \mathrm{C}\right)=150.13 \mathrm{ppm}(\mathrm{C}-4 \mathrm{a})$ is correlated with the $5-\mathrm{CH}_{2}$ protons $\left(3.38\right.$ and $3.86 \mathrm{ppm}$ ) and weakly with $6 . \mathrm{CH}_{3}$ protons $(1.71 \mathrm{ppm})$ and $7-\mathrm{NH}(8.82 \mathrm{ppm})$.

The dihedral angle between $\mathrm{C}-8 \mathrm{a}$ and the $5-\mathrm{CH}_{2}$ proton $\mathrm{Ha}$ is $92.2^{\circ}$ and between proton $\mathrm{Hb},-150.4^{\circ}$. Because $\mathrm{C}$ $8 \mathrm{a}$ is more strongly correlated with the $3.86 \mathrm{ppm}$ than with the $3.38 \mathrm{ppm}$ proton shift, the former one must belong to $\mathrm{Hb}$ and the latter to $\mathrm{Ha}$.

The $\delta\left({ }^{15} \mathrm{~N}\right)=-227.7 \mathrm{ppm}$ and $-248.2 \mathrm{ppm}$ were assigned from the PFG ${ }^{1} \mathrm{H},{ }^{15} \mathrm{~N}$ HMBC spectrum, where their ${ }^{1} J\left({ }^{1} \mathrm{H},{ }^{15} \mathrm{~N}\right)$ with $\mathrm{NH}\left(11.46 \mathrm{ppm}\right.$, ring A) and $\mathrm{NH}(8.82 \mathrm{ppm}$, ring $\mathrm{D})$ were observed. The $\delta\left({ }^{15} \mathrm{~N}\right)=-248.2 \mathrm{ppm}$ is also strongly correlated with $5-\mathrm{CH}_{2}(3.38$ and $3.86 \mathrm{ppm})$ and $6-\mathrm{CH}_{3}(1.71 \mathrm{ppm})$ protons. The $\delta\left({ }^{15} \mathrm{~N}\right)=-227.7 \mathrm{ppm}$ is correlated with the aromatic ring protons $\mathrm{H}-2(7.01 \mathrm{ppm}$, ring $\mathrm{A})$ and $\mathrm{H}-6(6.88 \mathrm{ppm}$, ring $\mathrm{A})$.

The most shielded non protonated $\delta\left({ }^{15} \mathrm{~N}\right)=-160.0 \mathrm{ppm}$, must belong to the $\mathrm{sp}^{3}$-hybridized $\mathrm{N}-2$ (ring C) (15). It is correlated with all the aromatic ring protons $\mathrm{H}-2, \mathrm{H}-5$ and $\mathrm{H}-6(7.13,7.22$ and $7.15 \mathrm{ppm}$, ring $\mathrm{B})$, which confirms the interpretation. The $\delta\left({ }^{15} \mathrm{~N}\right)=-34.6 \mathrm{ppm}$ is correlated with NH proton shift of $11.46 \mathrm{ppm}$ (ring A) and belongs to the hydrazono nitrogen $\mathrm{C}=\mathrm{N}$. Thus the $\delta\left({ }^{15} \mathrm{~N}\right)=-25.3 \mathrm{ppm}$ belongs to the $\mathrm{N}-1$ in ring $\mathrm{C}$. It is weakly correlated with the $\mathrm{NH}$ proton of ring $\mathrm{D}(8.82 \mathrm{ppm})$.

The cyano nitrogen does not give any cross peak in the PFG ${ }^{1} \mathrm{H},{ }^{15} \mathrm{~N}$ HMBC measurement being five bonds away from the nearest protons.

After the assignment of all the ${ }^{1} \mathrm{H},{ }^{13} \mathrm{C}$ and ${ }^{15} \mathrm{~N}$ NMR shifts of compound 1 , those for compound 2 were much more straightforward. The aromatic ring $\delta\left({ }^{1} \mathrm{H}\right)$ shifts deviated most from each other in compounds 1 and 2 . The interpretation of the ${ }^{1} \mathrm{H},{ }^{13} \mathrm{C}$ and ${ }^{15} \mathrm{~N}$ NMR shifts in compound 2 is based as above on the ${ }^{n} J(\mathrm{H}, \mathrm{H})$ values, DQF ${ }^{1} \mathrm{H},{ }^{1} \mathrm{H}$ COSY, PFG ${ }^{1} \mathrm{H}, \mathrm{X}\left(\mathrm{X}={ }^{13} \mathrm{C},{ }^{15} \mathrm{~N}\right) \mathrm{HMQC}$ and $\mathrm{HMBC}$ experiments.

\section{Acknowledgment}

The authors are grateful to Spec.lab.technicians Reijo Kauppinen and Mirja Lahtiperä for the measurement of the NMR and mass spectra, and to Dr. Maija Nissinen for assisting in elucidation the X-ray data.

\section{References}

1. N.S. Ibrahim, F.M. Abdel-Galil, R.M. Abdel-Motaleb and M.H. Elnagdi, Bull. Chem. Soc. Japan, 60, 4486 (1967)

2. S. Kambe, K. Saito, M. Hirose, A. Sakarai and H. Midorikawa, Synthesis, 860 (1984).

3. F.J. Cuadrado, M.A. Perez and J.L. Soto, J. Chem. Soc. Perkin Trans. 1, 2447 (1984).

4. M.H. Elnagdi, H.A. Elfahham, S.A.S. Ghozlan and G.E.H. Elgemeie, J. Chem. Soc. Perkin Trans. 1, 2667 (1982) 
5. R.E. Hurd and B.K. John, J. Magn. Reson. 91, 648 (1991).

6. A. Bax, R.H. Griffey and B.L. Hawkins, J. Magn. Reson. 55, 301 (1983).

7. A. Bax and S. Subramanian, J. Magn. Reson. 67, 565 (1986).

8. A. Bax and M.F. Summers, J. Am. Chem. Soc. 108, 2093 (1986).

9. M. Rance, O.W. Sörensen, G. Bodenhausen, G. Wagner, R.R. Ernst and K. Wutrich, Biochem. Biophys. Res. Commun. 117, 479 (1948).

10. A. Derome and M. Williamson, J. Magn. Reson. 88, 117 (1990).

11. Z. Otwinowski and W. Minor, Methods in Enzymology, Macromolecular Crystallography, Part A, in C.W. Carter, Jr. and R.M. Sweet (Ed.), pp. 307-326, Academic Press, New York, 1997.

12. G.M. Sheldrick, SHELXS-97, A Program for Automatic Solution of Crystal Structures, University of Göttingen, Germany, 1997.

13. G.M. Sheldrick, SHELXL-97, A Program for Crystal Structure Refinement, University of Göttingen, Germany, 1997.

14. E. Breitmaier and W. Voelter, Carbon-13 NMR Spectroscopy, in VCH (Ed.), New York, 1987.

15. S. Berger, S. Braun and H.O. Kalinowski, NMR Spectroscopy of the Non-Metallic Elements, in John Wiley \& Sons Ltd (Ed.), England, 1997.

\section{Received on October 10, 2003.}

